Org Biomol Chem. 2018 December 19; 17(1): 151-155. doi:10.1039/c8ob02677g.

\title{
Stereoselective synthesis of chromane derivatives via a domino reaction catalyzed by modularly designed organocatalysts
}

\author{
Satish Jakkampudi, Ramarao Parella, and John C.-G. Zhao \\ Department of Chemistry, University of Texas at San, Antonio One UTSA Circle, San Antonio, TX \\ 78249-0698, USA.
}

\begin{abstract}
A highly enantio- and diastereoselective method for the synthesis of functionalized chroman-2ones and chromanes was achieved by using an organocatalytic domino Michael/hemiacetalization reaction of aliphatic aldehydes and (E)-2-(2-nitrovinyl)phenols followed by a PCC oxidation and dehydroxylation, respectively. Using the modularly designed organocatalysts (MDOs) selfassembled from cinchona alkaloid derivatives and amino acids in the reaction media, the title products were obtained in good to high yields (up to 97\%) and diastereoselectivities (up to 99:1 dr) and excellent enantioselectivities (up to $99 \%$ ee).
\end{abstract}

\section{Graphical Abstract}

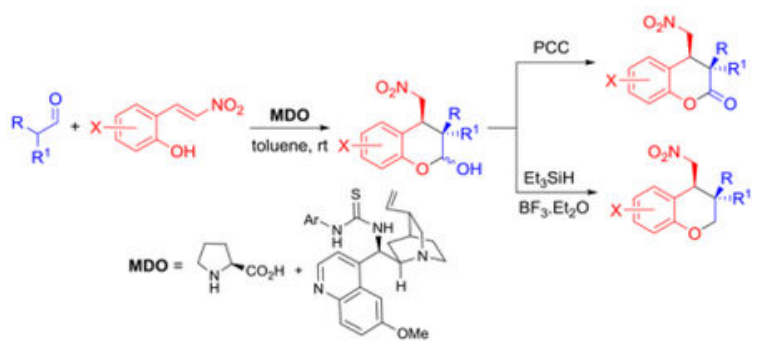

\section{Introduction}

Michael addition to nitroalkenes is a powerful tool in organic synthesis that enables the synthesis of complex organic molecules bearing the synthetically useful nitro group. Not surprisingly, organocatalytic nitro-Michael reactions have been extensive investigated in the past decades. ${ }^{1}$

Chroman-2-one and chromane are important classes of benzopyran derivatives. ${ }^{1}$ The dihydrocoumarin and chromane scaffolds are found in many natural products and synthetic molecules that frequently exhibits unique biological and pharmacological activities, ${ }^{2}$ such as antineoplastic activity, ${ }^{3}$ antiherpetic activity, ${ }^{4}$ and the inhibitive activities against protein kinases,${ }^{5}$ aldose reductase, ${ }^{6}$ and HIV-1 reverse transcriptase. ${ }^{7}$ Owing to the importance of

Conflicts of interest

There are no conflicts to declare.

Electronic Supplementary Information (ESI) available: [copy of NMR spectra and HPLC chromatograms]. 
the chromane scaffold, its stereoselective synthesis has attracted considerable attention. ${ }^{8}$ Indeed, several organocatalytic methods have been developed to access this core structure in an asymmetric manner. ${ }^{9-13}$ For examples, Ramachary, ${ }^{9}$ Enders, ${ }^{10}$ Gong, ${ }^{11}$ and Hong ${ }^{12}$ have independently developed organocatalytic domino ${ }^{14}$ Michael/hemiacetalization reactions followed by an oxidation reaction for the efficient synthesis of chroman-2-one derivatives in a highly stereoselective manner.

Our group is interested in developing novel catalytic methods ${ }^{15}$ using the modularly designed organocatalysts (MDOs), ${ }^{16,17}$ which are self-assembled in the reaction media from cinchona alkaloid derivatives and amino acids. Herein, we wish to report that, using MDOs as the catalysts, the reaction between aliphatic aldehydes and (E)-2-(2-nitrovinyl)phenols gives the expected domino Michael/hemiacetalization products, which may be converted to functionalized chroman-2-ones and chromanes by PCC oxidation and dehydroxylation, respectively (Scheme 1). The desired chroman-2-ones and chromanes were both obtained in good yields and high stereoselectivities.

\section{Results and discussion}

Hydrocinnamaldehyde (1a) and (E)-2-(2-nitrovinyl)phenol (2a) was adopted as the model substrates. Several cinchona alkaloid derivatives and amino acids (Figure 1) were adopted as the precatalyst modules. These two modules have complementary basic and acidic functional groups that can help them self-assemble in situ in the reaction media. The most interesting results of the catalyst screening are collected in Table 1 . As the results in Table 1 show, when quinidine thiourea $\mathbf{6 a}$ and L-proline (7a) were adopted as the stereocontrolling module and the reaction-center module, respectively, the reaction of 1a and 2a gave product 4a (after oxidation with PCC) in a high yield (94\%) and excellent diastereoselectivity (96:4 dr) and ee value (99\%, entry 1). Control experiments conducted with either $6 \mathbf{a}$ or $7 \mathbf{a}$ alone as the catalyst did not yield any product under otherwise identical conditions (entries 2 and 3). These results confirm that the observed catalytic activity is indeed due to the in-situ generated MDO.

Similar results were obtained when the MDO self-assembled from cinchonine thiourea $\mathbf{6 b}$ and 7a was applied, except that the obtained product yield (80\%) and diastereoselectivity (87:13 dr) were slightly lower (entry 4). Much lower product ee value (78\% ee) was obtained when the MDO 6c/7a was employed as the catalyst (entry 5). The MDO 6d/7a yielded very similar stereoselectivities as $\mathbf{6} \mathbf{c} / 7 \mathbf{a}$ did, but the product yield $(97 \%)$ was much better (entry 6). Similar results were also obtained for the MDOs 6e/7a and $\mathbf{6 f} / 7 \mathbf{a}$ (entries 7 8). In contrast, a poor product ee value ( $32 \%$ ee) was obtained when the MDO $6 \mathbf{g} / 7 \mathbf{a}$ was applied (entry 9). These screening identified the stereocontrolling module 6a is the best one for this reaction in terms both the product yield and stereoselectivities (entry 1). Using $\mathbf{6 a}$ as the stereocontrolling module, we next screened several amino acids as the reaction-center module. The pseudo-diastereomeric MDO formed from $\mathbf{6 a}$ and D-proline (7b) led to the formation of the enantiomer of $\mathbf{4 a}$ in a high yield, but only moderate stereoselectivities (84:16 dr, 75\% ee) (entry 10). Very good results were also obtained from the MDO $6 \mathbf{a} / 7 \mathbf{c}$ (entry 11 ), which was only slightly inferior to that of $\mathbf{6 a / 7}$ a (entry 1 ). However, almost no product could be isolated from the reaction catalyzed by the MDO self-assembled from $\mathbf{6 a}$ 
and L-thioproline (7d) (entry 12). Thus, the above screening identified MDO 6a/7a (entry 1) as the best catalyst for this domino Michael/hemiacetalization reaction. Next the solvent was screened for this best MDO. Common organic solvents, such as xylenes (entry 13), benzene (entry 14), and $\mathrm{CH}_{2} \mathrm{Cl}_{2}$ (entry 15) all yielded inferior diastereoselectivities. Slightly inferior results in terms of both yield and stereoselectivities were also obtained from the environmentally benign solvent cyclopentyl methyl ether (entry 16). On the other hand, much poorer product ee value was obtained (14\% ee) in $\mathrm{MeOH}$ (entry 17). THF (entry 18), 1,4-dioxane (entry 19), and $\mathrm{CH}_{3} \mathrm{CN}$ (entry 20) also turned out to be poor solvents for this reaction since either only trace amount product or no product could be obtained from these solvents. When the catalyst loading was reduced to $5 \mathrm{~mol} \%$, the yield and stereoselectivities obtained for $\mathbf{4 a}$ were only slightly lower (entry 21 ).

Once the reaction conditions were optimized, the scope of this reaction was studied and the results are collected in Table 2. As the results in Table 2 show, besides hydrocinnamaldehyde (1a, entry 1), other linear aldehydes, such as propanal (entry 2), butanal (entry 3), pentanal (entry 4), heptanal (entry 5), also react with (E)-2-(2-nitrovinyl)phenol (2a) to give the desired chroman-2-ones $\mathbf{4 b - e}$ after oxidation in high yields (83-97\%), good to excellent diastereoselectivities (81:19 to 98:2 dr), and excellent ee values (97-99\% ee). In general, higher diastereoselectivities were obtained with longer chain aldehyde substrates. With the branched 3-methylbutanal high diastereoselectivity of 99:1 dr and enantioselectivity of $93 \%$ ee were obtained for the corresponding chroman-2-one $\mathbf{4 f}$ (entry 6). Similarly, 2methylpropanal also yielded the expected $\mathbf{4 g}$ after oxidation in $96 \%$ ee, although in a lower yield (69\%, entry 7). Using pentanal as the aldehyde component, various substituted (E)-2(2-nitrovinyl)phenols were then screened. It was found that these substituted $(E)-2-(2-$ nitrovinyl)phenols usually led to slightly lower yields (65-87\%) and diastereoselectivities (80:20 to $95: 5 \mathrm{dr}$ ) of the corresponding chroman-2-ones (4h-n, entries 8-14) as compared to those obtained from the unsubstituted (E)-2-(2-nitrovinyl)phenol (entry 4). However, the product ee values remained high (entries 8-14). On the other hand, the electronic nature and the position of the substituent on the phenyl ring of (E)-2-(2-nitrovinyl)phenol had no significant effects on the diastereoselectivities or the product ee values (entries 8-14), except that a slightly lower ee value was obtained for the chroman-2-one product of the 4-nitrosubstituted phenol (entry 10). Using the branched 3-methylbutanal as the aldehyde component yielded comparable results with those of pentanal (entries 15-16 vs. 8-9).

To demonstrate the synthetic utility of this method, the same reaction was also carried out at $0.5-\mathrm{mmol}$ scale of 1a and 2a. As the results in Table 2 show, product 4a was obtained in comparable yield, diastereoselectivity, and ee value as those of the small-scale reaction (entry 17 vs. entry 1 ).

To obtain the 3,4-substituted chromanes $\mathbf{5}$, the primary domino Michael/hemiacetalization products 3 were dehydroxylated by treating with triethylsilane and boron trifluoride diethyl etherate in dichloromethane (Table 3). As shown in Table 3, the dehydroxylation reaction provided the desired products 5a-c in good to excellent yields (72-94\%) with preservation of the diastereoselectivities (85:15 to 95:5 dr:) and enantioselectivities of the domino reaction (92 to $98 \%$ ee). 
The absolute stereochemistry of the major enantiomeric products of compounds $\mathbf{4}$ and $\mathbf{5}$ was determined as shown in the Tables by comparing the measured optical rotation of compounds $\mathbf{4 d}$ and $\mathbf{5 a}$ with those reported in the literature. ${ }^{12}$ Based on the product stereochemistry and a recent computational study our MDO catalytic system, ${ }^{18}$ a plausible transition state is proposed to account for the formation of the major stereoisomer of the domino Michael/hemiacetalization reaction (Scheme 2). As shown in Scheme 2, the $\mathrm{Si}$-Si attack of the preferred $s y n-(E)$-enamine ${ }^{18}$ of hydrocinnamaldehyde onto the $(E)$-2-(2nitrovinyl)phenol (2a) yields the Michael addition intermediate $\mathbf{6}$ with the expected stereochemistry of the two stereogenic centers, which, after an intramolecular hemiacetalization reaction, gives product 3a. Product 3a yields the expected $4 \mathbf{a}$ upon oxidation.

\section{Experimental}

\section{Representative procedure for the synthesis of chroman-2-ones via the domino Michael/ hemiacetalization followed by an oxidation reaction:}

To a vial were added sequentially the precatalyst modules $6 \mathbf{6}(5.9 \mathrm{mg}, 0.010 \mathrm{mmol}, 10.0 \mathrm{~mol}$ $\%)$ and $7 \mathbf{a}(1.1 \mathrm{mg}, 0.010 \mathrm{mmol}, 10.0 \mathrm{~mol} \%)$ and dry toluene $(1.0 \mathrm{~mL})$. The resulting mixture was stirred at room temperature for $15 \mathrm{~min}$. Compound $1 \mathrm{a}(16.0 \mathrm{mg}, 0.12 \mathrm{mmol}, 1.2$ equiv.) was then added and the mixture was further stirred for $5 \mathrm{~min}$. before the addition of compound $2 \mathrm{a}$ ( $16.5 \mathrm{mg}, 0.1 \mathrm{mmol}, 1.0$ equiv.). The resulting solution was stirred at room temperature for $16 \mathrm{~h}$ until the reaction was complete (monitored by TLC). Then the reaction mixture was concentrated under reduced pressure and the residue was purified by flash column chromatography to give the chroman-2-ol 3a as a colorless oil (29.9 mg). A solution of the chroman-2-ol 3a (29.9 mg, $0.10 \mathrm{mmol})$ in $\mathrm{CH}_{2} \mathrm{Cl}_{2}(3.0 \mathrm{~mL})$ and PCC (64.5 mg, 0.30 mmol, 3.0 equiv.) was stirred at room temperature for $24 \mathrm{~h}$ until the completion of reaction (monitored by TLC). The suspension was filtered through a short pad of silica gel and washed with ethyl acetate. Removing the solvents under reduced pressure afforded the crude product 4a, which was then purified by flash chromatography (30:70 EtOAc/hexane as the eluent) to afford product $\mathbf{4 a}(28.0 \mathrm{mg}, 94 \%)$ as a colorless oil.

\section{General procedure of the dehydroxylation reaction:}

10,12 To a solution of chroman-2-ol $\mathbf{3}(0.10 \mathrm{mmol}, 1.0$ equiv. $)$ in $\mathrm{CH}_{2} \mathrm{Cl}_{2}(3.0 \mathrm{~mL})$ at $0{ }^{\circ} \mathrm{C}$ were added triethylsilane ( $34.9 \mathrm{mg}, 0.30 \mathrm{mmol}, 3.0$ equiv.) and boron trifluoride etherate (42.6 mg, $0.30 \mathrm{mmol}, 3.0$ equiv.) with stirring. The ice bath was removed after $15 \mathrm{~min}$ and the mixture was further stirred for $2 \mathrm{~h}$. Then the reaction was quenched with saturated aqueous $\mathrm{NaHCO}_{3}$ solution $(3 \mathrm{~mL})$ and the mixture was extracted with $\mathrm{CH}_{2} \mathrm{Cl}_{2}(3 \times 20 \mathrm{~mL})$. The combined organic phases were dried over $\mathrm{MgSO}_{4}$ and the solvent was evaporated under reduced pressure. The crude product was purified by flash chromatography on silica gel to afford the corresponding chromane $\mathbf{5}$.

\section{Conclusions}

In summary, we have developed a highly stereoselective synthesis of cis-3,4-disubstituted chroman-2-ones and chromanes using a domino Michael/hemiacetalization-reaction of 
aliphatic aldehydes and (E)-2-(2-nitrovinyl)phenols catalyzed by modularly designed organocatalysts (MDOs) followed by a PCC oxidation or dehydroxylation. The corresponding chroman-2-ones and chromanes were obtained in good to excellent yields and diastereomeric ratios and high ee values.

\section{Supplementary Material}

Refer to Web version on PubMed Central for supplementary material.

\section{Acknowledgements}

The generous financial support of this research from the National Science Foundation (grant No. CHE 1664278) and the Welch Foundation (Grant No. AX-1593) was gratefully acknowledged. Some of the NMR data reported in this paper were collected on an NMR spectrometer acquired with the funding from the NSF (Grant No. CHE-1625963). The HRMS used in this research was supported by a grant from the National Institute on Minority Health and Health Disparities (G12MD007591) from the National Institutes of Health. The authors also thank Dr. Wendell P. Griffith for help with the HRMS analysis of the samples.

\section{Notes and references}

1. For reviews, see:Enders D, Wang C and Liebich JX, Chem. Eur. J, 2009, 15, 11058-11076; [PubMed: 19798719] Tsogoeva SB, Eur. J. Org. Chem, 2007, 1701-1716;Berner Otto M., Tedeschi L and Enders D, Eur. J. Org. Chem, 2002, 1877-1894;Sulzer-Mossé S and Alexakis A, Chem. Commun, 2007, 3123-3135;Vicario JL, Badía D and Carrillo L, Synthesis, 2007, 14, 20652092;Almaşi D, Alonso DA and Nájera C, Tetrahedron: Asymmetry, 2007, 18, 299-365;Faisca Phillips AM, Curr. Org. Synth, 2016, 13, 687-725.

2. (a)Murray RDH, Mendez J and Brown SA, The Natural Coumarins: Occurrence, Chemistry, and Biochemistry; Wiley: New York, 1982;(b)O'Kennedy R and Thornes RD, Coumarins: Biology, Applications, and Mode of Action, 1st ed.; Wiley: New York, 1997;(c)Nicolaou KC, Pfefferkorn JA, Roecker AJ, Cao GQ, Barluenga S and Mitchell HJ, J. Am. Chem. Soc, 2000, 122, 9939-9953; (d)Schweizer EE, Meeder-Nycz O, In Chromenes, Chromanes, Chromones; Ellis GP Ed., WileyInterscience: New York, 1977;(e)Kumar A, Singh BK, Tyagi R, Jain SK, Sharma SK, Prasad AK, Raj HG, Rastogi RC, Watterson AC and Parmar VS, Bioorg. Med. Chem, 2005, 13, 4300-4305; [PubMed: 15878663] (f)Posakony J, Hirao M, Stevens S, Simon JA and Bedalov A, J. Med. Chem, 2004, 47, 2635-2644; [PubMed: 15115404] (g)Zhang X.-f., Wang H.-m., Song Y.-1., Nie L.-h., Wang L.-f., Liu B, Shen P.-p. and Liu Y, Bioorg. Med. Chem. Lett, 2006, 16, 949-953. [PubMed: 16297615]

3. Jurd L, J. Heterocycl. Chem, 1997, 34, 601-604.

4. Takechi M, Tanaka Y, Takehara M, Nonaka G-I and Nishioka I, Phytochem, 1985, 24, 2245-2250.

5. Hsu F, Nonaka G and Nishioka I, Chem. Pharm. Bull, 1985, 33, 3142-3152.

6. Iinuma M, Tanaka T, Mizuno M, Katsuzaki T and Ogawa H, Chem. Pharm. Bull, 1989, 37, 18131815. [PubMed: 2509087]

7. Tillekeratne LMV, Sherette A, Grossman P, Hupe L, Hupe D and Hudson RA, Bioorg. Med. Chem. Lett, 2001, 11, 2763-2767. [PubMed: 11591519]

8. (a)Zhang Z-P, Chen L, Li X and Cheng J-P, J. Org. Chem, 2018, 83, 2714-2724; [PubMed: 29406716] (b)Cui L, Lv D, Wang Y, Fan Z, Li Z and Zhou Z, J. Org. Chem, 2018, 83, 4221-4228; [PubMed: 29533621] (c)Kim H and Yun J, Adv. Synth. Catal, 2010, 352, 1881-1885;(d)Matsuda T, Shigeno M and Murakami M, J. Am. Chem. Soc, 2007, 129, 12086-12087; [PubMed: 17877354] (e)Li J-L, Zhou S-L, Han B, Wu L and Chen Y-C, Chem. Commun, 2010, 46, 2665-2667;(f)Han X and Lu X, Org. Lett, 2010, 12, 108-111; [PubMed: 19968313] (g)Alden-Danforth E, Scerba MT and Lectka T, Org. Lett, 2008, 10, 4951-4953. [PubMed: 18850717]

9. (a)Ramachary DB and Sakthidevi R, Org. Biomol. Chem, 2010, 8, 4259-4265; [PubMed: 20676460] (b)Ramachary DB and Sakthidevi R, Chem. Eur. J, 2009, 15, 4516-4522. [PubMed: 19308984] 
10. (a)Enders D, Yang X, Wang C, Raabe G and Runsik J, Chem. Asian J, 2011, 6, 2255-2259; [PubMed: 21735556] (b)Enders D, Wang C, Yang X and Raabe G, Adv. Synth. Catal, 2010, 352, 2869-2874.

11. (a)Hong B-C, Kotame P and Liao J-H, Org. Biomol. Chem, 2011, 9, 382-386; [PubMed: 21088771] (b)Hong B-C, Kotame P, Tsai C-W and Liao J-H, Org. Lett, 2010, 12, 776-779; [PubMed: 20078081] (c)Kotame P, Hong B-C and Liao J-H, Tetrahedron Lett, 2009, 50, 704-707.

12. Lu D, Li Y and Gong Y, J. Org. Chem, 2010, 75, 6900-6907. [PubMed: 20857918]

13. (a)Zhang T, Ma C, Zhou J-Y, Mei G-J and Shi F, Adv. Synth. Catal, 2018, 360, 1128-1137.; (b)Yang X, Zhang Y-C, Zhu Q-N, Tu M-S and Shi F, J. Org. Chem, 2016, 81, 5056-5065.; [PubMed: 27164054] (c)Zhang Y-C, Zhu Q-N, Yang X, Zhou L-J and Shi F, J. Org. Chem, 2016, 81, 1681-1688.; [PubMed: 26800116] (d)Zhao J-J, Sun S-B, He S-H, Wu Q and Shi F, Angew. Chem. Int. Ed, 2015, 54, 5460-5464.;(e)Jiang X-L, Wu S-F, Wang J-R, Mei G-J and Shi F, Adv. Synth. Catal, 2018, 360, 4225-4235.

14. For reviews, see:Pellissier H, Adv. Synth. Catal, 2012, 354, 237-294;Chauhan P, Mahajan S, Kaya U, Hack D and Enders D, Adv. Synth. Catal, 2015, 357, 253-281;Chanda T and Zhao JC-G, Adv. Synth. Catal, 2018, 360, 2-79. Wang C, Yang X, Raabe G and Enders D, Adv. Synth. Catal, 2012, 354, 2629-2634;Wu Z, Wang X, Li F, Wu J and Wang J, Org. Lett, 2015, 17, 3588-3591; [PubMed: 26147230] Massolo E, Palmieri S, Benaglia M, Capriati V and Perna FM, Green Chem, 2016, 18, 792-797.

15. (a)Rana NK, Huang H and Zhao JC-G, Angew. Chem. Int. Ed, 2014, 53, 7619-7623;(b)Huang H, Konda S and Zhao JC-G Angew. Chem. Int. Ed, 2016, 55, 2213-2216;(c)Bihani M and Zhao JCG, Adv. Synth. Catal, 2017, 359, 534-575.

16. (a)Mandal T and Zhao C-G, Angew. Chem. Int. Ed, 2008, 47, 7714-7717;(b)Muramulla S and Zhao C-G, Tetrahedron Lett, 2011, 52, 3905-3908;(c)Sinha D, Mandal T, Gogoi S, Goldman JJ and Zhao JC-G, Chin. J. Chem, 2012, 30, 2624-2630;(d)Muramulla S, Ma J-A and Zhao JC-G, Adv. Synth. Catal, 2013, 355, 1260-1264;(e)Sinha D, Perera S and Zhao JC-G, Chem. Eur. J, 2013, 19, 6976-6979; [PubMed: 23613314] (f)Perera S, Sinha D, Rana NK, Trieu-Do V and Zhao JC-G, J. Org. Chem, 2013, 78, 10947-10953; [PubMed: 24106958] (g)Konda S and Zhao JC-G, Tetrahedron, 2018, 74, 6166-6172;(h)Parella R, Jakkampudi S, Arman H and Zhao JC-G, Adv. Synth. Catal, in press, DOI: 10.1002/adsc.201800987.

17. Additional examples of using MDOs as the catalysts:Ramachary DB, Sakthidevi R and Shruthi KS, Chem. Eur. J, 2012, 18, 8008-8012; [PubMed: 22649025] Ramachary DB and Shruthi KS, Org. Biomol. Chem, 2014, 12, 4300-4304; [PubMed: 24840771] Ramachary DB, Shruthi KS and Madhavachary R, Euro. J. Org. Chem, 2015, 6413-6418.Hang Z, Zhu J, Lian X, Xu P, Yu H and Han S, Chem. Commun, 2016, 52, 80-83.

18. Bhaskararao B and Sunoj RB, Chem. Sci, 2018, 9, 8738-8747.

Org Biomol Chem. Author manuscript; available in PMC 2019 December 19. 

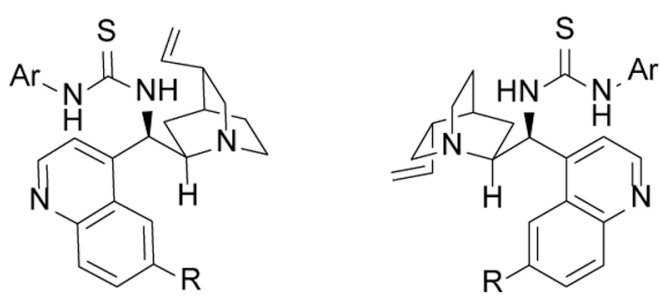

6c: $\mathrm{R}=\mathrm{OMe}$

6a: $\mathrm{R}=\mathrm{OMe}$

6b: $\mathrm{R}=\mathrm{H}$

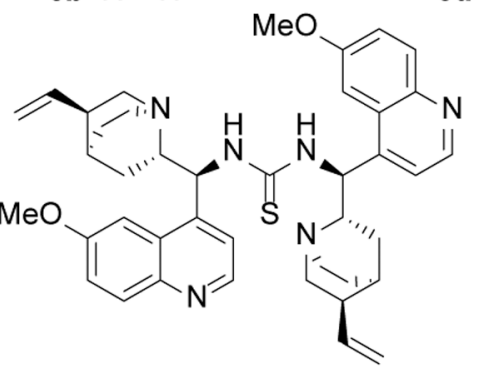

$6 f$<smiles>O=C(O)[C@H]1CCCN1</smiles>

$7 a$<smiles>O=C(O)[C@H]1CCCN1</smiles>

$7 b$

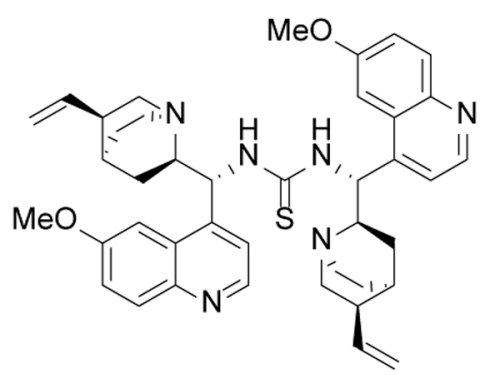

$6 \mathrm{~g}$<smiles>O=C(O)[C@@H]1CSCN1</smiles>

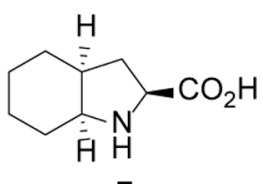

Figure 1.

Structure of the precatalyst modules $\left[\mathrm{Ar}=3,5-\left(\mathrm{CF}_{3}\right)_{2} \mathrm{C}_{6} \mathrm{H}_{3}-\right.$ ]. 


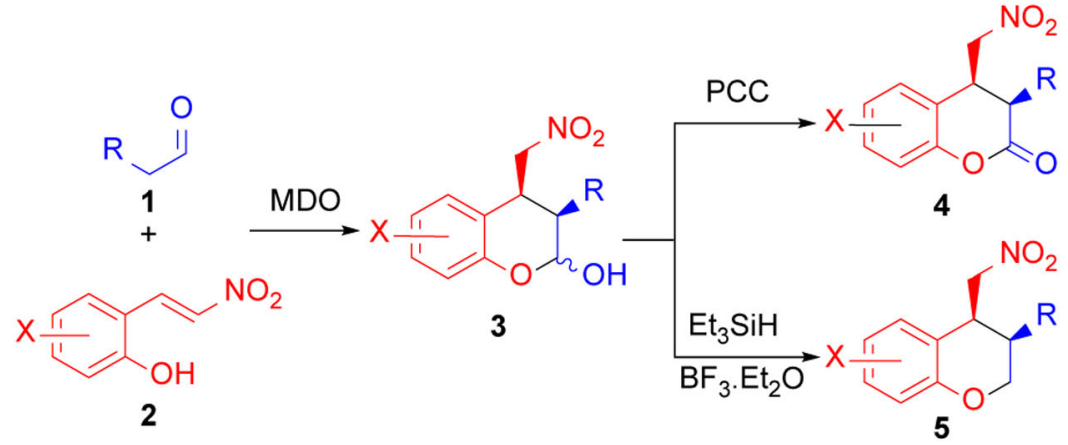

Scheme 1.

Synthesis of chroman-2-ones and chromanes using MDOs as the catalysts 

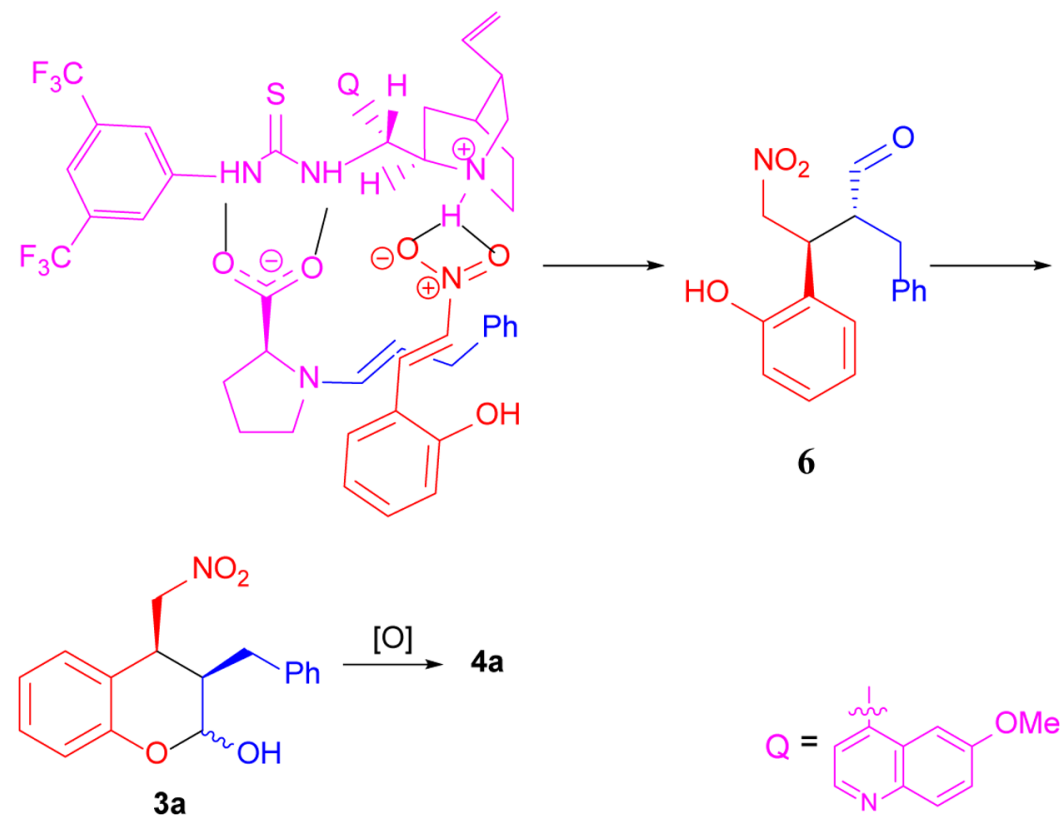

Scheme 2.

Proposed transition state that accounts for the formation of the major stereoisomer.

Org Biomol Chem. Author manuscript; available in PMC 2019 December 19. 


\section{Table 1}

Catalyst screening and optimization of the reaction conditions ${ }^{a}$

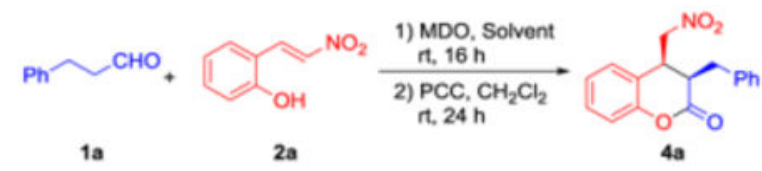

\begin{tabular}{|c|c|c|c|c|c|c|}
\hline Entry & Mo & ules & Solvent & Yield $^{b}(\%)$ & $\mathrm{dr}^{c}$ & $\mathrm{ee}^{d}(\%)$ \\
\hline 1 & $6 a$ & $7 a$ & Toluene & 94 & $96: 4$ & 99 \\
\hline 2 & $6 a$ & --- & Toluene & --- & --- & --- \\
\hline 3 & --- & $7 a$ & Toluene & --- & --- & --- \\
\hline 4 & $6 b$ & $7 a$ & Toluene & 80 & $87: 13$ & 98 \\
\hline 5 & $6 c$ & $7 a$ & Toluene & 80 & $81: 19$ & 78 \\
\hline 6 & 6d & $7 a$ & Toluene & 97 & $83: 17$ & 78 \\
\hline 7 & $6 e$ & $7 a$ & Toluene & 90 & $85: 15$ & 87 \\
\hline 8 & $6 f$ & $7 a$ & Toluene & 87 & $84: 16$ & 84 \\
\hline 9 & $6 \mathrm{~g}$ & $7 a$ & Toluene & 80 & $80: 20$ & 32 \\
\hline 10 & $6 a$ & $7 b$ & Toluene & 97 & $84: 16$ & $75^{e}$ \\
\hline 11 & $6 a$ & $7 \mathrm{c}$ & Toluene & 94 & $88: 12$ & 98 \\
\hline 12 & $6 a$ & $7 d$ & Toluene & $<5$ & --- & --- \\
\hline 13 & $6 a$ & $7 a$ & Xylenes $^{f}$ & 99 & $88: 12$ & 99 \\
\hline 14 & $6 a$ & $7 a$ & Benzene & 99 & $80: 20$ & 99 \\
\hline 15 & $6 a$ & $7 a$ & $\mathrm{CH}_{2} \mathrm{Cl}_{2}$ & 87 & $82: 18$ & 96 \\
\hline 16 & $6 a$ & $7 a$ & $\mathrm{CPME}^{g}$ & 70 & $95: 5$ & 91 \\
\hline 17 & $6 a$ & $7 a$ & $\mathrm{MeOH}$ & 94 & $84: 16$ & 14 \\
\hline 18 & $6 a$ & $7 a$ & THF & $<5$ & --- & --- \\
\hline 19 & $6 a$ & $7 a$ & 1,4-Dioxane & --- & --- & --- \\
\hline 20 & $6 a$ & $7 a$ & $\mathrm{CH}_{3} \mathrm{CN}$ & --- & --- & --- \\
\hline $21^{h}$ & $6 a$ & $7 a$ & Toluene & 89 & $93: 7$ & 98 \\
\hline
\end{tabular}

${ }^{a}$ Unless otherwise specified, all reactions were carried out with $\mathbf{1 a}(0.12 \mathrm{mmol}), \mathbf{2 a}(0.10 \mathrm{mmol})$, and the precatalyst modules $(0.010 \mathrm{mmol}$ each, 10 $\mathrm{mol} \%)$ in dry toluene $(1.0 \mathrm{~mL}$ ) at room temperature for $16 \mathrm{~h}$. Once the reaction was complete, the initial products were purified by flash column chromatography and then oxidized with PCC (3.0 equiv.) in $\mathrm{CH}_{2} \mathrm{Cl}_{2}$ at $\mathrm{rt}$ for $24 \mathrm{~h}$.

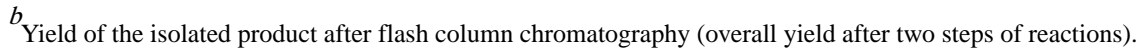

${ }^{c}$ Determined by ${ }^{1} \mathrm{H}$ NMR analysis of the crude product.

${ }^{d}$ Determined by HPLC analysis on a ChiralPak AD-H column.

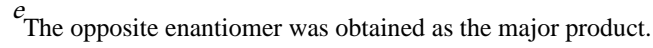

$f_{\text {A mixture of all dimethylbenzene isomers. }}$

${ }^{g}$ Cyclopentyl methyl ether.

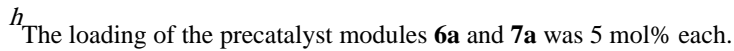

Org Biomol Chem. Author manuscript; available in PMC 2019 December 19. 


\section{Table 2}

Substrate scope of the domino Michael/hemiacetalization reactions ${ }^{a}$

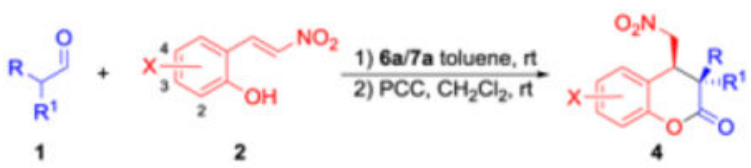

\begin{tabular}{|c|c|c|c|c|c|c|}
\hline Entry & $\mathbf{R}$ & $\mathbf{R}^{1}$ & $\mathbf{X}$ & $4 /$ Yield $^{b}(\%)$ & $\mathrm{dr}^{c}$ & $\mathrm{ee}^{d}(\%)$ \\
\hline 1 & $\mathrm{Bn}$ & $\mathrm{H}$ & $\mathrm{H}$ & $4 a / 94$ & $96: 4$ & 99 \\
\hline 2 & $\mathrm{Me}$ & $\mathrm{H}$ & $\mathrm{H}$ & $4 b / 86$ & $89: 11$ & 99 \\
\hline 3 & Et & $\mathrm{H}$ & $\mathrm{H}$ & $4 \mathbf{c} / 97$ & $81: 19$ & 96 \\
\hline 4 & $n-\operatorname{Pr}$ & $\mathrm{H}$ & $\mathrm{H}$ & $4 d / 83$ & $98: 2$ & 96 \\
\hline 5 & $n$-Pent & $\mathrm{H}$ & $\mathrm{H}$ & $4 e / 90$ & $95: 5$ & 97 \\
\hline 6 & $i-\operatorname{Pr}$ & $\mathrm{H}$ & $\mathrm{H}$ & $\mathbf{4 f} / 91$ & $99: 1$ & 93 \\
\hline $7^{e}$ & $\mathrm{Me}$ & $\mathrm{Me}$ & $\mathrm{H}$ & $4 g / 69$ & --- & 96 \\
\hline $8^{f}$ & $n-\operatorname{Pr}$ & $\mathrm{H}$ & $4-\mathrm{Cl}$ & $4 h / 74$ & $84: 16$ & 98 \\
\hline $9^{f}$ & $n-\operatorname{Pr}$ & $\mathrm{H}$ & $4-\mathrm{Br}$ & $4 \mathbf{i} / 73$ & $85: 15$ & 98 \\
\hline $10^{f}$ & $n-\operatorname{Pr}$ & $\mathrm{H}$ & $4-\mathrm{NO}_{2}$ & $4 \mathbf{j} / 68$ & $80: 20$ & 87 \\
\hline 11 & $n-\operatorname{Pr}$ & $\mathrm{H}$ & 4-Me & $4 k / 68$ & $89: 11$ & 96 \\
\hline $12^{f}$ & $n-\operatorname{Pr}$ & $\mathrm{H}$ & 4-OMe & $41 / 72$ & $80: 20$ & 96 \\
\hline $13^{f}$ & $n-\operatorname{Pr}$ & $\mathrm{H}$ & $2-\mathrm{Me}$ & $4 m / 65$ & $95: 5$ & 98 \\
\hline 14 & $n-\operatorname{Pr}$ & $\mathrm{H}$ & $3-\mathrm{Me}$ & $4 n / 87$ & $89: 11$ & 99 \\
\hline $15^{f}$ & $i-\operatorname{Pr}$ & $\mathrm{H}$ & $4-\mathrm{Cl}$ & $40 / 74$ & $98: 2$ & 98 \\
\hline $16^{f}$ & $i-\operatorname{Pr}$ & $\mathrm{H}$ & $4-\mathrm{Br}$ & $4 p / 73$ & $87: 13$ & 89 \\
\hline $17^{g}$ & $\mathrm{Bn}$ & $\mathrm{H}$ & $\mathrm{H}$ & $4 a / 90$ & $94: 6$ & 98 \\
\hline
\end{tabular}

${ }^{a}$ Unless otherwise specified, all reactions were carried out with $\mathbf{1}(0.12 \mathrm{mmol}), \mathbf{2}(0.10 \mathrm{mmol})$, and the precatalyst modules $6 \mathbf{a}$ and $7 \mathbf{a}(0.010 \mathrm{mmol}$ each, $10 \mathrm{~mol} \%)$ in dry toluene $(1.0 \mathrm{~mL})$ at room temperature for $16 \mathrm{~h}$. Once the reaction was complete, the initial products were purified by flash column chromatography and then oxidized with PCC (3.0 equiv.) in $\mathrm{CH}_{2} \mathrm{Cl}_{2}$ at $\mathrm{rt}$ for $24 \mathrm{~h}$.

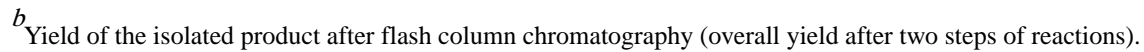

${ }^{c}$ Determined by ${ }^{1} \mathrm{H}$ NMR analysis of the crude product.

${ }^{d}$ Determined by HPLC analysis on ChiralPak AD-H, OD-H, or IC columns. The absolute stereochemistry was assigned by comparing the measured optical rotation of compound $\mathbf{4 d}$ with that reported in the literature (Ref. 12).

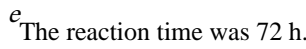

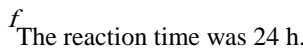

$g_{\text {Reaction performed in } 0.50 \mathrm{mmol} \text { scale. }}$

Org Biomol Chem. Author manuscript; available in PMC 2019 December 19. 


\section{Table 3}

Converting the primary hemiacetal products 3 to chromanes $\mathbf{5}$ via dehydroxylation ${ }^{a}$

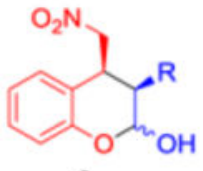

3

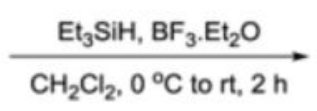

$\mathrm{CH}_{2} \mathrm{Cl}_{2}, 0^{\circ} \mathrm{C}$ to $\mathrm{rt}, 2 \mathrm{~h}$

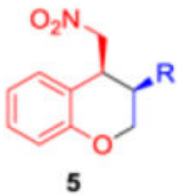

5

\begin{tabular}{ccccc}
\hline Entry & $\mathbf{R}$ & $\mathbf{5 / Y i e l d ~}^{\boldsymbol{b}}(\boldsymbol{\%})$ & $\mathbf{d r}^{\boldsymbol{c}}$ & $\mathbf{e e}^{\boldsymbol{d}(\boldsymbol{\%})}$ \\
\hline 1 & Et & $\mathbf{5 a} / 90$ & $88: 12$ & 98 \\
2 & $n-\operatorname{Pr}$ & $\mathbf{5 b} / 94$ & $85: 15$ & 98 \\
3 & $i-\operatorname{Pr}$ & $\mathbf{5 c} / 72$ & $95: 5$ & 92
\end{tabular}

${ }^{a}$ Unless otherwise specified, all reactions were carried out with $\mathbf{3}(0.10 \mathrm{mmol})$, triethylsilane $(0.30 \mathrm{mmol})$, and boron trifluoride diethyl etherate $(0.30 \mathrm{mmol})$ in $\mathrm{CH}_{2} \mathrm{Cl}_{2}(3.0 \mathrm{~mL})$ at $0{ }^{\circ} \mathrm{C}$ to room temperature for $2 \mathrm{~h}$.

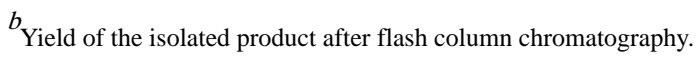

${ }^{c}$ Determined by ${ }^{1} \mathrm{H}$ NMR analysis of the crude product.

$d$ Determined by HPLC analysis on ChiralPak OD-H or IB columns. The absolute stereochemistry was assigned by comparing the measured optical rotation of compound $\mathbf{5 a}$ with that reported in the literature (Ref. 12). 